\title{
Materiales cementicios utilizados en el almacenamiento español de residuos de media y baja radiactividad
}

\author{
Cemented materials in the $L L W$ and MLW spanish disposal
}

Fecha de recepción: 3-XII-98
Fecha de aceptación: 25-III-99
A.GUERRERO,M.S.HERNÁNDEZyS.GOÑI Instituto de Ciencias de la Construcción Eduardo Torroja (CSIC)

\section{RESUMEN}

Matrices cementicias confinantes tipo BWR y PWR de residuos simulados de baja y media radiactividad se han sometido a procesos de lixiviación en agua desionizada a $20{ }^{\circ} \mathrm{C}$ y $40{ }^{\circ} \mathrm{C}$, obteniéndose los indices medios de lixiviación (L) y el coeficiente de difusión efectiva (De) de algunos iones. Por otra parte, se ha estudiado la expansión asociada a un mortero de relleno constitutivo del depósito de almacenamiento de los residuos, por posible ataque de los iones $\mathrm{SO}_{4}{ }^{2-}$ procedentes de las matrices.

\section{SUMMARY}

BWR and PWR cemented matrices to confine low and medium simulated liquid radioactive wastes have been submitted to the leaching process in de-ionized water at $20^{\circ} \mathrm{C}$ and $40^{\circ} \mathrm{C}$, to obtain the medium leachability index (L) and the effective diffusion coefficient $\left(D_{c}\right)$ of different ions. Otherwise, it has been studied the associated expansion of the backfilling mortar of the concrete containers of the spanish repository of these wastes, due to a possible attack of the sulfate ions coming from the cemented matrices.

\section{INTRODUCCIÓN}

El incremento de materiales residuales de carácter tóxico-peligroso, en general, y radiactivo, en particular, ha supuesto el desarrollo de nuevas líneas de investigación relacionadas con su tratamiento, clasificación, gestión, etc.

La peligrosidad de los residuos radiactivos radica en el largo período de tiempo que necesitan para agotar sus niveles de radiación ionizante y convertirse así en residuos estables. Es por esto, que su gestión y tratamiento es de vital importancia, basándose, principalmente, en procesos de estabilización y solidificación (1), para un posterior almacenamiento a largo plazo, en lugares donde se asegure su aislamiento de la biosfera.

\section{INTRODUCTION}

The increase of dangerous and toxic wastes, specially the radioactive ones, has developped new investigation lines related to the waste management.

The risk of radioactive wastes is due above all to the long time they need to eliminate the radioactivity levels and to become stable wastes. That is why their management is so important. It is based on stabilization and solidification processes (1), being afterwards stored for a long term, where the isolation from the biosphere can be ensured. 
En los sistemas de estabilización/solidificación, para la inmovilización y confinamiento de los residuos de media y baja radiactividad (RMR y RBR), se están empleando masivamente materiales solidificantes "en base cemento", siendo el cemento Portland uno de los más utilizados $(2,3,4)$, ya que es el material más empleado en construcción que presenta una serie de ventajas, entre las que cabe destacar:

\section{Material de partida barato}

\section{Buena durabilidad}

3. Las reacciones con este material son similares, en determinados aspectos, a las que tienen lugar con otros utilizados en los procesos de solidificación y fijación química (puzolanas, cenizas volantes, etc.).

4. Proporciona inmovilización química y física, además de una alta alcalinidad que impide la fijación microbiana.

En España, el centro de almacenamiento de residuos de baja y media radiactividad está diseñado para asegurar el confinamiento de dichos residuos durante, al menos, 300 años, que es el tiempo calculado necesario para que agoten sus niveles de emisión radiactiva. Este emplazamiento denominado "El Cabril", ubicado en el noroeste de la provincia de Córdoba, está constituido, fundamentalmente, por 3 barreras de ingeniería aislantes superpuestas $(5,6)$. En la primera de ellas, es donde el cemento juega un papel importante como confinante de residuos. Por un lado, en la matriz de inmovilización, el cemento forma parte integral de ella, mezclándose con los residuos y, por otro, en el contenedor de almacenamiento, forma parte de un mortero, denominado Mortero de Relleno. Éste inmoviliza lo depositado en el contenedor.

Según recomendaciones elaboradas por Comités Científicos de la Comunidad Europea $(7,8)$, para el empleo de las màtrices confinantes, se ha de tener pleno conocimiento de sus características. Por lo que se han de tener en cuenta aspectos como: la caracterización y optimización de las matrices, valoraciones sobre ellas y, muy importante, conocimientos sobre su comportamiento durable.

Se han ensayado, en una primera parte del trabajo, matrices confinantes donde el residuo simulado está constituido por concentrados de evaporador tipo BWR (Boiling Water Reactor) y PWR (Pression Water Reactor) y que han sido fabricadas amasando estas soluciones con dos tipos diferentes de cemento Portland, evaluando su eficacia por procesos de lixiviación. El ataque al mortero de relleno, que forma parte de la primera barrera de ingeniería del almacenamiento, por posibles iones sulfato procedentes
In the stabilization/solidification systems, for the immobilization and solidification of low and medium radioactive wastes (LRW and $M R W$ ), different kinds of cementitious materials have been employed; the ordinary Portland cement (OPC) is the most frequently used (2, 3, 4), because it presents a lot of advantages. Among these can be pointed up:

\section{Cheap starting material}

\section{Good durability}

3. The reactions with this material are very similar to those produced by others materials used in solidification and chemical processes, as fly ash, pozzolans, etc.

4. Supplies physical and chemical immobilization, and a high alkalinity that could avoid the microbial fixation.

In Spain, the storage place for low and medium level radioactive wastes was designed to ensure their confining during 300 years, which is the time calculated to exhaust their radioactive emission levels. This storage, called "El Cabril", is situated in the mountains of Cordoba. It is constituted, mainly, by three superpose engineering barriers of isolation $(5,6)$. In the first one, is where the cement plays the most important role as a waste confining material. In one hand, in the immobilization matrices the cement is an inner part of them, mixed with the wastes; in other hand, in the storage container, as a part of a specific mortar, named "Backfilling Mortar". This mortar will immobilize the wastes in the container.

According to the recommendations of Scientific European Committees $(7,8)$ in order to employ the cementitious matrices, it is necessary to have a full acknowledgment of their characteristics, so it is need to take in account some aspects such as: characterization, optimization and valoration of the matrices and above all acknowledgement about their durability behaviour.

In the first part of this work two different confining matrices have being tested, in which the simulated liquid wastes are evaporator concentrate solutions synthetized in the laboratory: Boiling Water Reactor "BWR" and Pressure Water Reactor "PWR", respectively. Matrices were fabricated by mixing the $B W R$ and PWR solutions with two different kinds of ordinary Portland cement (OPC). The efficiency of the matrices to confine the soluble ions from the solutions was evaluated by a leaching test. In a 
de dichas matrices, así como su posible expansión asociada, ha sido considerado en segundo término.

\subsection{Caracterización y Eficacia de Matrices Confinantes: Ensayo de Lixiviación}

El ataque por lixiviación es uno de los mejores métodos para evaluar la eficacia de un material como sistema de inmovilización de residuos $(3,4,9$, entre otros).

En este trabajo se han sometido matrices tipo BWR y PWR, a procesos de lixiviación que sirven para medir, en general, la capacidad de migración de cualquier especie iónica, radiactiva o no, hacia el exterior de sus matrices confinantes, empleando, para ello, el ensayo ANSI/ANS-16.1-1986 (10), a las temperaturas de $20^{\circ} \mathrm{C}$ y $40^{\circ} \mathrm{C}$.

Estos ensayos permiten la acumulación de suficientes datos, en un corto período de tiempo (días o meses), con los que, mediante un tratamiento matemático adecuado, se pueden determinar una serie de parámetros intrínsecos a cada tipo de matriz. A partir de los cuales, es posible obtener una clasificación del material, que indica la eficacia como confinador de un determinado ión y que viene definida por el valor del llamado "Índice de Capacidad de Lixiviación(L)".

\subsection{Estudio de Expansión asociada al posible} ataque de los iones procedentes de las matrices

Los iones que acompañan a los residuos tales como: sulfatos, sodio, potasio, calcio, boratos, fosfatos, etc., pueden resultar perjudiciales para las estructuras de cemento y hormigón del emplazamiento de los residuos de media y baja radiactividad.

Se presenta en este trabajo un estudio particular sobre la estabilidad dimensional de un mortero de relleno del contenedor de almacenamiento de los residuos mencionados, dentro de los que, sobre durabilidad, se están llevando a cabo con este material $(11,12)$. Para determinar la estabilidad dimensional, concretamente la expansión asociada al ataque de los iones sulfato procedentes de las matrices, se ha empleado el "Ensayo Normalizado ASTM C452-88".

En el caso de un contenedor de almacenamiento, la fuente de iones sulfato, puede ser del propio cemento o bien de las matrices de inmovilización, más concretamente de las sales disueltas en los concentrados de evaporador que contienen dichas matrices, por lo que se ha elegido una matriz tipo BWR con una alta concentración en iones sulfato, para hacer más drástico el ensayo. second part, it has been studied the mechanism of attack of the sulfate ions coming from the matrices to the backfilling mortar, as well as, the associated expansion.

\subsection{Leaching Test: Characterization and Efficiency of Cemented Matrices}

The leaching attack is one of the best methods to evaluate the efficiency of a material as a waste immobilization system (3,4,9 among other authors).

In this work, two matrices, type BWR and PWR, have been investigated by means of the leaching process to evaluate, in general, the capability of migration of any ionic species, radioactive or no, to the inside of confining matrices. It has been employed the American National Standard Institute leaching test ANSI/ANS 16.1-1986 (10). The experiments were carried out at two temperatures: $20^{\circ} \mathrm{C}$ and $40^{\circ} \mathrm{C}$.

This test gives, in a short period of time enough data, which treated with an adequate mathematical way, permit to obtain a serie of parameters characteristic for every matrix. From them it is possible to obtain a classification of the material, that indicates its efficiency to confine a specific ion. That efficiency is determined by the "Leachability Index" (L).

\subsection{Expansion associated to sulfate ions attack coming from cemented-based matrices.}

The sulfate, sodium, potassium, calcium, borate and phosphate ions, which go with the LLW ad MLW can become dangerous for the durability of the cement materials and concrete barriers employed in the storage of these radioactive wastes.

In this work, a particular study about the dimensional stability of a specific backfilling mortar, which is used in the concrete containers for that storage, is shown. Others interesting studies about durability of this material are carried out in our laboratory $(11,12)$. To determine the dimensional stability, specifically, the expansion associated to the sulfate attack coming from cemented-based matrices, a Standarized Test, the "ASTM C452-88", has been used.

In the case of the above mentioned concrete container, the source of sulfate ions, can be the cement itself and also the immobilization matrices and more exactly, the salts dissolved in the simulated liquid wastes in those matrices. The authors have chosen a BWR matrix, with a high concentration of sulfate ions, in order to make the dimensional stability test more drastic. 


\section{PARTE EXPERIMENTAL}

\subsection{Ensayo de Lixiviación}

Siguiendo las directrices de la norma ANSI/ANS-16.11986, se emplea, como líquido lixiviante, agua desmineralizada de conductividad $\sigma<5 \mu \Omega$, trabajando a temperatura ambiente, que puede oscilar entre 17,5 y $27,5^{\circ} \mathrm{C}$. Ensayos posteriores se realizaron a la temperatura de $40^{\circ} \mathrm{C}$,con el fin de operar en condiciones parecidas a las del citado emplazamiento español en época estival y de obtener resultados comparativos, acelerando los procesos del ensayo.

Como en trabajos precedentes (13), las muestras empleadas han sido probetas cilíndricas, de $10 \mathrm{~cm}$ de longitud por $5 \mathrm{~cm}$ de diámetro, cumpliendo la relación longitud/diámetro $=2$, dentro del intervalo establecido por la norma $(0,2-5)$. Las probetas se mantienen en bolsas de plástico, herméticamente cerradas, hasta el comienzo del test de lixiviación. Los recipientes empleados son botes de plástico, que no reaccionan con el agua, siendo la relación volumen de líquido/ superficie de la muestra expuesta al ataque de $10 \pm 0,2 \mathrm{~cm}$. Por lo tanto, de acuerdo con el tipo de probeta elegido $\left(\mathrm{S}=196,35 \mathrm{~cm}^{2}\right)$, ha sido preciso utilizar un volumen de 2 litros de agua.

El agua de lixiviado se renueva a los siguientes períodos de tiempo normalizados: $0,08 \mathrm{~d}, 0,3 \mathrm{~d}, 1 \mathrm{~d}, 2 \mathrm{~d}$, 3d, 4d, 5d, 19d, 47d y 90d, siendo la velocidad de migración una función de los mismos.

Se han realizado estos ensayos en dos matrices tipos BWR y PWR, constituidas por cemento amasado con residuos simulados (los concentrados de evaporador correspondientes). La composición de los materiales de partida figuran en las Tablas 1 y 2.

\subsection{Ensayo de Expansión}

El ensayo se ha llevado a cabo durante 1 año, a la temperatura de $40{ }^{\circ} \mathrm{C}$ y $90 \%$ HR. Efectuándose medidas de expansión con el comparador de longitudes, según la metodología del ensayo ASTM C452-88, en tres tipos de probetas: unas, fabricadas con el mortero de relleno; otras, con la matriz tipo BWR-B (con alto contenido en iones sulfato: $2,05 \mathrm{M} \mathrm{SO}_{4}{ }^{2-}$ ) y, por último, en probetas mixtas mortero/matriz BWR-B $(6,12)$. Las composiciones químicas de los materiales empleados se presentan en las Tablas 3, 4 y 5:

La Matriz confinante, denominada BWR-B, está constituida por cemento Portland tipo I-35A y concentrado de evaporador del mismo nombre; la composición química de cada componente se da en las Tablas 4 y 5 .

\section{EXPERIMENTAL PROCEDURE}

\subsection{Leaching Test}

Following the specifications of ANSI/ANS-16.1-1986, the leachant utilized was demineralized water with a conductivity $\sigma<5 \mu \Omega$. They have worked, at ambient temperature, between 17.5 and $27.5^{\circ} \mathrm{C}$ and also at $40^{\circ} \mathrm{C}$ with the purpose to obtain some comparative results, doing the chemical process more accelerated; besides to reach similar temperature conditions to those of the spanish disposal in summer time.

As in previous works (13), the samples employed were cylindrical probes of $10 \mathrm{~cm}$ long and $5 \mathrm{~cm}$ diameter, being length/diameter ratio of 2 , range ratio according to the standarized test (0.2-5). The samples are kept in plastic bags until the leaching test starts, the specimens were immersed in individual plastic containers employing a ratio of 10 $\mathrm{cm}$ between the volume of the leachant and the external geometric surface area of the specimen $\left(196.35 \mathrm{~cm}^{2}\right)$, for that reason the volume of the deionized water in the experiments was 2 liters.

The leachate was replaced periodically after intervals of static leaching, for cumulative leach times of 0.08 , $0.3,1,2,3,4,5,19,47$ and 90 days, being the rate of, a function of the leachant renewal frequency.

Matrix BWR was fabricated with ordinary portland cement as a solidification agent of simulated BWR-A concentrate solution, and matrix $P W R$ with a pozzolanic portland cement and a simulated PWR concentrate solutions. Both chemical compositions are given in Table 1 and 2.

\subsection{Expansion Test}

This test was carried out during 1 year at $40^{\circ} \mathrm{C}$ and $90 \%$ relative humidity ( $r h$ ). So the expansion value was obtained by the methodology of the standard test ASTM C452-88, in three different types of probes: some of them made with the backfilling mortar; others with cemented BWR-B matrix (with high concentration of sulfate ions: $2.05 \mathrm{M}$ of $\left.\mathrm{SO}_{4}{ }^{2-}\right)$ and finally in mixspecimens: backfilling mortar-BWR-B matrix $(6,12)$. The chemical compositions of starting materials are shown in the follow Tables 3, 4 and 5.

The confining matrix called BWR-B is constituted by ordinary portland cement type I-35 and a simulated radioactive liquid waste of the same name; the chemical composition of each component is given in Tables 4 and 5 . 
TABLA 1 (TABLE 1)

Análisis Químico de Los Cementos Constitutivos de las matrices BWR y PWR (\%) (Chemical Composition of the Cement in the BWR and PWR Matrices (\%))

\begin{tabular}{|c|c|c|c|c|c|c|c|c|c|c||}
\hline & P.F. & R.I. & $\mathrm{SiO}_{2}$ & $\mathrm{Al}_{2} \mathrm{O}_{3}$ & $\mathrm{Fe}_{2} \mathrm{O}_{3}$ & $\mathrm{CaO}$ & $\mathrm{MgO}$ & $\mathrm{SO}_{3}$ & $\mathrm{Na}_{2} \mathrm{O}$ & $\mathrm{K}_{2} \mathrm{O}$ \\
\hline $\begin{array}{c}\text { BWR-A } \\
\text { (Cem.I-35) }\end{array}$ & 2,40 & 2,49 & 17,90 & 6,50 & 2,73 & 60,80 & 2,80 & 3,10 & 0,12 & 1,20 \\
\hline $\begin{array}{c}\text { PWR } \\
\text { (Cem IV-35A) }\end{array}$ & 3,00 & 23,4 & 14,9 & 3,25 & 8,30 & 43,1 & 1,56 & 2,69 & 0,22 & 1,70 \\
\hline
\end{tabular}

TABLA 2 (TABLE 2)

Composición Química de los Concentrados de Evaporador de las Matrices BWR-A y PWR(g/l) (Chemical Composition of the Simulated Liquid Wastes: BWR-A and PWR (g/l)

\begin{tabular}{|c|c|c|c|c|c|c|c|c|}
\hline & $\mathrm{Na}_{2} \mathrm{SO}_{4}$ & $\mathrm{NaH}_{2} \mathrm{PO}_{4}$ & $\mathrm{NaH}_{2} \mathrm{HPO}_{4}$ & $\begin{array}{r}\mathrm{CaCl}_{2} \\
6 \mathrm{H}_{2} \mathrm{O}\end{array}$ & $\mathrm{Ca}_{3}\left(\mathrm{PO}_{4}\right)_{2}$ & $\begin{array}{c}\mathrm{FeCl}_{3} \cdot \\
6 \mathrm{H}_{2} \mathrm{O}\end{array}$ & $\mathrm{CsCl}$ & $\mathrm{H}_{3} \mathrm{BO}_{3}$ \\
\hline BWR-A & 95,64 & 29,92 & 59,88 & 8,76 & --- & 38,64 & 0,1 & --- \\
\hline PWR & 44,4 & $-\cdot$ & 35,5 & --- & 18,9 & --- & 0,1 & 138,7 \\
\hline
\end{tabular}

TABLA 3 (TABLE 3)

Análisis Qiímico del Cemento del Mortero de relleno (\%) (Chemical Analysis of the Cement in fthe Backfilling Mortar (\%)

\begin{tabular}{|c|c|c|c|c|c|c|c|c|c|c||}
\hline & P.F. & R.I. & $\mathrm{SiO}_{2}$ & $\mathrm{Al}_{2} \mathrm{O}_{3}$ & $\mathrm{Fe}_{2} \mathrm{O}_{3}$ & $\mathrm{CaO}$ & $\mathbf{M g O}$ & $\mathrm{SO}_{3}$ & $\mathrm{Na}_{2} \mathrm{O}$ & $\mathrm{K}_{2} \mathrm{O}$ \\
\hline IV-35A & 3,6 & 0,09 & 26 & 7,1 & 4,1 & 54 & 1,7 & 3,5 & 0,23 & 0,97 \\
\hline
\end{tabular}

TABLA 4 (TABLE 4)

Composición química del Cemento de la Matriz BWR-B(\%)

(Chemicel Composition of Cement in the BWR Matrix (\%)

\begin{tabular}{|c|c|c|c|c|c|c|c|c|c|c||}
\hline & P.F. & R.I. & $\mathrm{SiO}_{2}$ & $\mathrm{Al}_{2} \mathrm{O}_{3}$ & $\mathrm{Fe}_{2} \mathrm{O}_{3}$ & $\mathrm{CaO}$ & $\mathrm{MgO}$ & $\mathrm{SO}_{3}$ & $\mathrm{Na}_{2} \mathrm{O}$ & $\mathrm{K}_{2} \mathrm{O}$ \\
\hline$-35 \mathrm{~A}$ & 4,7 & 0,83 & 18 & 3,2 & 4,9 & 62 & 1,4 & 3,7 & 0,81 & 0,89 \\
\hline
\end{tabular}

TABLA 5 (TABLE 5)

Composición Química del Concentrado de Evaporador BWR-B(g/l) (Chemical Composition of Simulated Radiactive Liquid Wastes: BWR-B(g/I)

\begin{tabular}{|c|c|c|c|c|c|c|}
\hline & $\mathrm{pH}$ & $\begin{array}{c}\text { densidad } \\
\text { (density } \\
\text { (g/cc) }\end{array}$ & $\mathrm{NaSO}_{4}$ & $\mathrm{Na}_{3} \mathrm{PO}_{4}$ & $\mathrm{Na}_{2} \mathrm{C}_{2} \mathrm{O}_{4}$ & $\mathrm{C}_{16} \mathrm{H}_{14} \mathrm{~N}_{2} \mathrm{NaO}_{8} \cdot 2 \mathrm{H}_{2} \mathrm{O}$ \\
\hline BWR-B & 7,5 & 1,2 & 291 & 0,34 & 0,35 & $\mathrm{KCl}$ \\
\hline
\end{tabular}


La precisión de la medida, que se realizó sobre 4 probetas prismáticas de dimensiones $25,4 \times 25,4 \times 287 \mathrm{~mm}$, fue de $0,001 \mathrm{~mm}$. La primera medida, que será de referencia, se efectuó al momento de desmoldar las probetas. Las siguientes se obtuvieron diariamente durante los primeros 90 días, se espaciaron posteriormente cada semana, hasta la conclusión del ensayo.

\section{RESULTADOS Y DISCUSIÓN}

\subsection{Ensayo de Lixiviación}

Con los datos de los análisis correspondientes a los cinco primeros días $(120 \mathrm{~h})$ se obtiene el llamado test abreviado. En este corto período de tiempo, el mecanismo que regula la migración iónica hacia el exterior, suele ser difusión pura; por lo que se puede aplicar la segunda Ley de Fick (estado de flujo no estacionario) para el cálculo del coeficiente de difusión efectiva $\left(\mathrm{D}_{\mathrm{e}}\right)$.

A partir de 5 días, otros mecanismos, como solubilización, erosión, etc., suelen intervenir en el proceso de lixiviación y sólo se pueden detectar con el test a largo plazo (90 días). Sin embargo, se ha considerado interesante la prolongación del test hasta un año o más, con el fin de conseguir una mayor degradación del material y poder analizar, de forma exhaustiva, los mecanismos de dicho proceso degradativo.

Los parámetros más importantes del ensayo son el índice de lixiviación (L) y el coeficiente de difusión efectiva $\left(D_{\mathrm{e}}\right)$ :

$\mathrm{L}=\log \left(\beta / \mathrm{D}_{\mathrm{e}}\right) ; \beta=1,0\left(\mathrm{~cm}^{2} \cdot \mathrm{s}^{-1}\right)$ constante definida

El valor de $L$ determina la eficacia de una matriz como confinante de un determinado ión. El valor 6 es la frontera que delimita esta capacidad del material.

Un valor superior del índice de lixiviación indica que la matriz ensayada será un buen material inmovilizador del ión correspondiente.

Se presentan los resultados obtenidos de los ensayos de lixiviación en la Tabla 6, donde se pueden ver los valores de $\mathrm{L}$ y $\mathrm{D}_{\theta}$ para los principales iones analizados en los lixiviados de ambas matrices BWR-A y PWR.

De los valores obtenidos de $D_{e}$ y $L$, se desprende que la matriz PWR tiene un mayor poder confinante que la BWR-A y, para ambas, es mayor a $20^{\circ} \mathrm{C}$. En general, los iones sulfato y calcio presentan menor capacidad de difusión que $\mathrm{Cl}^{-}, \mathrm{K}^{+}, \mathrm{Na}^{+}$y $\mathrm{Cs}^{+}$.
The accuracy of measure, done in four prismatic specimens of $25.4 \times 25.4 \times 287 \mathrm{~mm}$ dimensions, was $0.001 \mathrm{~mm}$. The first measure, which will be the reference, was taken immediately after demolding the specimens. The following measures were obtained daily during the first 90 days and later every week until finishing the test.

\section{RESULTS AND DISCUSSION}

\subsection{Leaching Test}

With the data obtained from the analyses during the first days $(120 \mathrm{~h})$ the abbreviated test is run out. In this short period of time the mechanism, which regulates the ionic migration to the outside of the matrix, is difussion. So the Fick's second law may be used to determine the effective diffusion coeficient.

After 5 days, other mechanisms, such as solubilization, erosion can take part in the leaching process and will be detected by the long term test ( 90 days). However, it has been considered interesting to extend the duration of the leaching test until 1 year to get a higher degradation of the matrices.

The most representative parameters of the leaching test are the leachability index $(L)$ and the effective diffusion coefficient $\left(D_{e}\right)$ :

$L=\log \left(\beta / D_{e}\right) ; \quad \beta=1.0\left(\mathrm{~cm}^{2} \cdot \mathrm{s}^{-1}\right)$ defined constant

The value of " $L$ " determines the efficiency of a matrix as a confining material of a specific ion. The value 6 is the frontier for this consideration. Highest values indicate that the tested matrix will be a good confining material for that ion.

In Table 6 are given the results obtained for $L$ and $D_{e}$ parameters to the different ions analyzed in the leachate solution of both matrices BWR-A and PWR.

From these values it can be deduced that PWR matrix has a higher confining capacity than BWR-A matrix. For both matrices this capacity is higher at $20^{\circ} \mathrm{C}$ and, in general, sulfate and calcium ions have lower diffusion capacity than chloride, sodium, potassium and cesium ions. 
TABLA 6/TABLE 6

Índices medios de Lixiviación $(L)$ y Coeficientes de Difusión Efectiva $\left(D_{e}\right)$

(Leachability Index $(L)$ and Effective Diffusion Coefficients $\left(D_{e}\right)$

\begin{tabular}{|c|c|c|c|c|c|c|c|c|}
\hline \multirow[t]{3}{*}{ Ión } & \multicolumn{4}{|c|}{ BWR-A } & \multicolumn{4}{|c|}{ PWR } \\
\hline & \multicolumn{2}{|c|}{$L$} & \multicolumn{2}{|c|}{$D_{0}\left(\mathrm{~cm}^{2} / \mathrm{s}\right)$} & \multicolumn{2}{|c|}{$\mathbf{L}$} & \multicolumn{2}{|c|}{$D_{0}\left(\mathrm{~cm}^{2} / \mathrm{s}\right)$} \\
\hline & $20^{\circ} \mathrm{C}$ & $40^{\circ \mathrm{C}}$ & $20^{\circ} \mathrm{C}$ & $40^{\circ} \mathrm{C}$ & $20^{\circ} \mathrm{C}$ & $40^{\circ} \mathrm{C}$ & $20^{\circ} \mathrm{C}$ & $40^{\circ} \mathrm{C}$ \\
\hline $\mathrm{Cs}$ & 6,8 & 6,7 & $1,7 \mathrm{E}-07$ & $2,0 E-07$ & 7,2 & 6,3 & $5,9 \mathrm{E}-08$ & $5,9 \mathrm{E}-07$ \\
\hline $\mathrm{Na}^{+}$ & 7,3 & 6,8 & $5,5 \mathrm{E}-08$ & $1,7 \mathrm{E}-07$ & 8,7 & 7,0 & $1,8 \mathrm{E}-08$ & $1,8 \mathrm{E}-07$ \\
\hline $\mathrm{K}^{+}$ & 7,2 & 6,2 & $7,2 \mathrm{E}-08$ & $6,3 \mathrm{E}-07$ & 7,6 & 7,7 & $5,9 \mathrm{E}-08$ & $2,8 \mathrm{E}-08$ \\
\hline $\mathrm{Cl}$ & 7,4 & 6,7 & $4,5 \mathrm{E}-08$ & $1,8 \mathrm{E}-07$ & --- & --- & --- & --- \\
\hline $\mathrm{Ca}^{2 \cdot}$ & 9,1 & 8,9 & $1,2 \mathrm{E}-09$ & $2,0 \mathrm{E}-09$ & 10,7 & 10,0 & $3,6 \mathrm{E}-11$ & $9,2 \mathrm{E}-11$ \\
\hline $\mathrm{SO}_{4}{ }^{2}$ & 9,5 & 8,9 & $2,4 \mathrm{E}-10$ & $1,1 \mathrm{E}-09$ & 8,6 & 9,7 & $1,9 \mathrm{E}-9,7$ & $1,8 \mathrm{E}-10$ \\
\hline
\end{tabular}

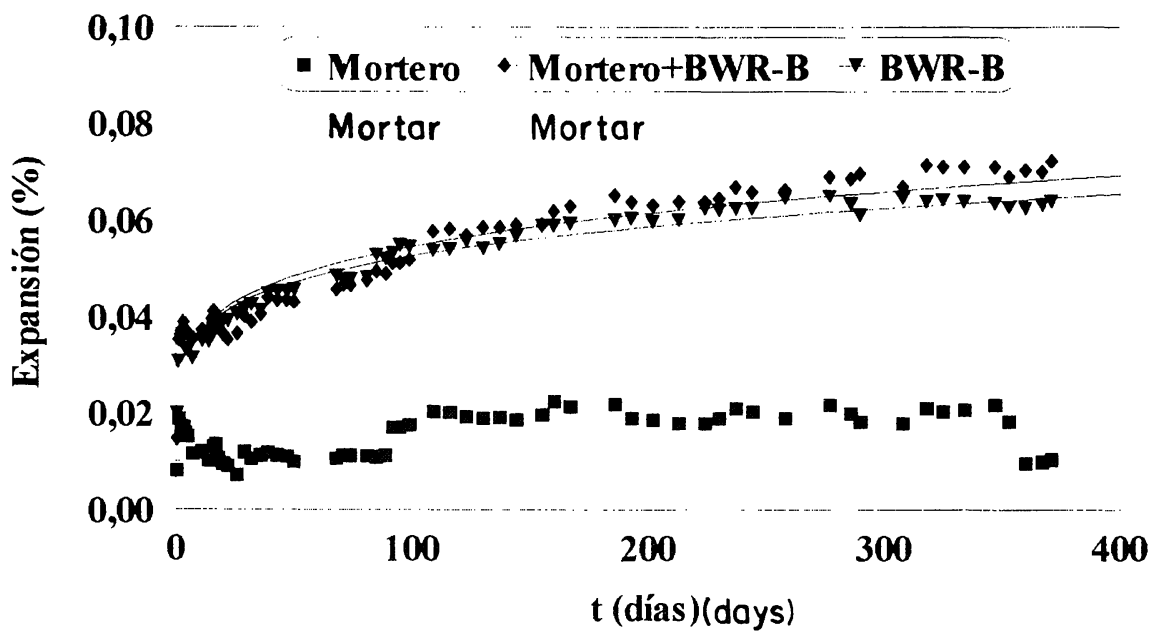

Figura 1.- Medidas de Expansión Relativa frente al Tiempo.

Figure 1.- Relative Expansion versus Time.

\subsection{Ensayo de Expansión}

De acuerdo con la normativa consultada, los límites de expansión tolerables a 14 días, están comprendidos entre $0,02-0,04 \%$, aunque en determinados hormigones, expuestos al ataque de sulfatos alcalinos, se permiten expansiones hasta del $0,1 \%$. $(14,15)$. Tal y como se puede ver en la Figura 1, el mortero parece no sufrir expansiones importantes a lo largo de la experimentación, no sobrepasando en ningún momento el valor límite arriba indicado. Si se comparan los resultados de los ensayos realizados con el mortero en contacto con la matriz BWR-B, con los de la propia matriz, se observa que en ambos casos se registra una

\subsection{Expansion Test}

According to the consulted standardized data, the accepted expansion values are, at 14 days, around $0.02-0.04 \%$, although in some concretes exposed to the effect of alkaline sulfate, is even allowed a expansion value of $0.1 \%(14,15)$. In Figure 1, it can be seen the expansion associated to the specimens fabricated with backfilling mortar, BWR-B matrix and also the mixspecimens backfilling mortar- $B W R-B$ matrix, respectively; with the time the specimen fabricated by the mortar does not experiment important dangerous expansion. This material does not reach the value limit above mentioned. However, the other two specimens considered have a similar evolution in their 
expansión similar. A primeras edades, las probetas experimentan una rápida expansión, que, con el tiempo, llega a estabilizarse, en valores comprendidos aproximadamente entre $0,06-0,07 \%$.

Estos fenómenos de expansión observados se reflejan en los resultados obtenidos por porosimetría de intrusión de mercurio. En la Figura 2, se comprueba la mayor porosidad de la matriz BWR-B frente a la del mortero aislado.

Cuando los materiales sufren expansiones y su porosidad total aumenta, indica que suceden en su microestructura procesos de nucleación y precipitación de compuestos de un tamaño mayor al que puede ser albergado en los poros. Para liberar el exceso de energía producido por la nucleación de nuevas fases cristalinas, se crean microfisuras en el material, en las cuales pueden recristalizar fases. Por Microscopía Electrónica de Barrido, se pueden observar, en la Figura 3(a): finas agujas de portlandita creciendo en una grieta y cristales de tenardita $\left(\mathrm{Na}_{2} \mathrm{SO}_{4}\right)$ y otros de gran tamaño, de naturaleza cálcica (Figura 3(b)), en zona de matriz. considered have a similar evolution in their dimensional expansion with the time. At the first ages the probes have a quickly expansion until 90 days, that seems to become stable when the expasion values are 0.06-0.07\%.

These phenomena observed in the dimensional expansion can be supported with the results from the total porosity. As can be seen in Figure 2, the total porosity in the case of the specimens fabricated with BWR-B matrix is higher than the porosity of the mortar probes.

If the materials experiment expansive processes and so their total porosity increase, that is an indication of some changes that occur in the microstructure, such as crystal growing and precipitation of molecules with a bigger size than the porous diameter. To release the energy excess, produced by the nucleation of new crystalline phases, it can be create some microcracks; in them growth of new phases can occur. By SEM, in Figure 3(a) it can be observed: fine needles of portlandite growing in the microcracks of the sample and tenardite $\left(\mathrm{Na}_{2} \mathrm{SO}_{4}\right)$ crystals as well as others of great sizes, with calcium in their structure, located in the matrix (Figure 3(b)).

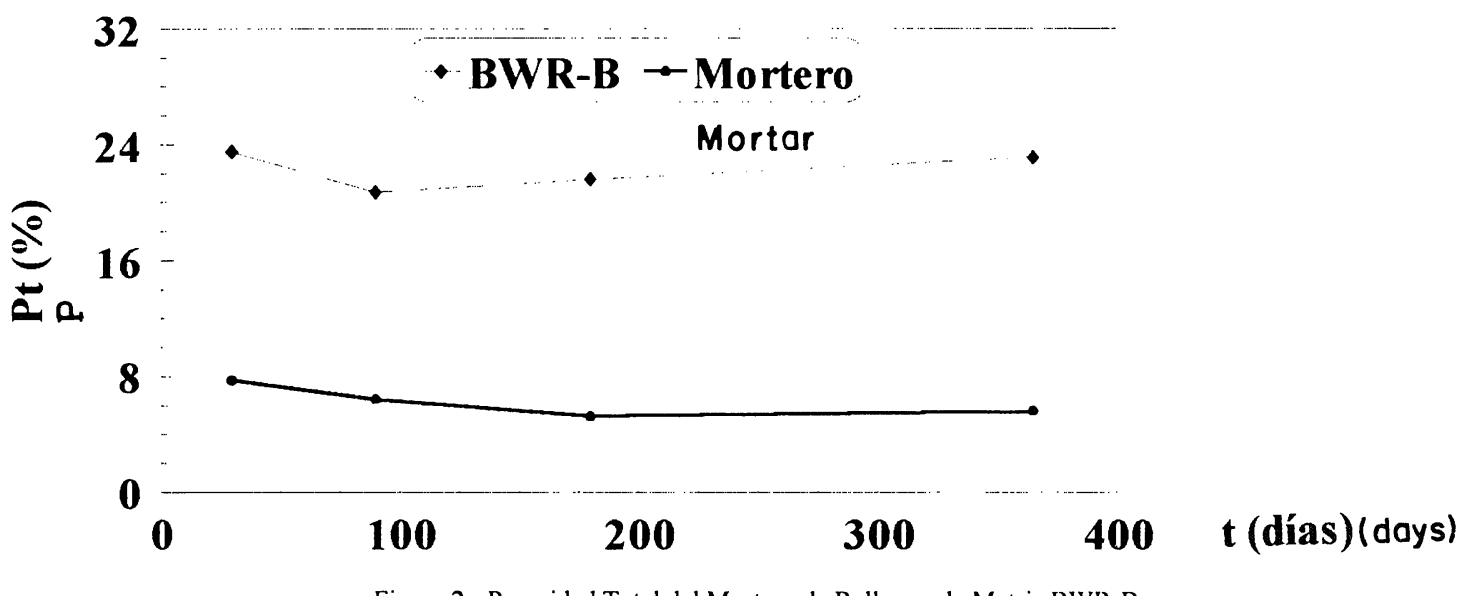

Figura 2.- Porosidad Total del Mortero de Relleno y la Matriz BWR-B.

Figure 2.- Total Porosity of Specimens fabricated with Backfilling Mortar and BWR-B Matrix.
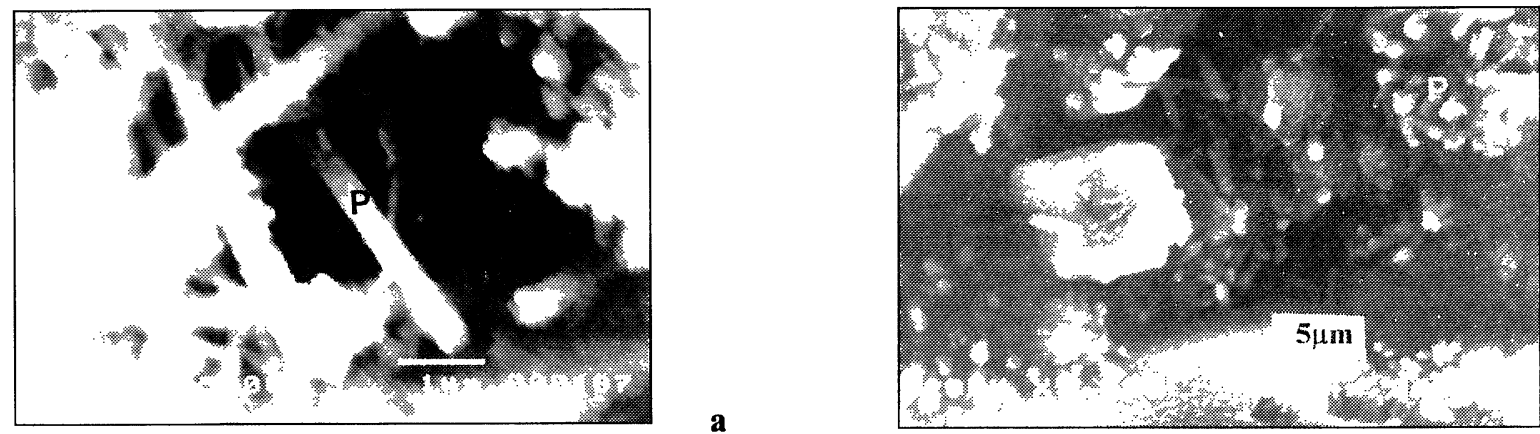

Figura 3.- Aspecto de la Microestructura de la Matriz BWR-B durante 1 año, a $40^{\circ} \mathrm{C}$. (a) Finas agujas de portlandita en una grieta; (b) Cristales de tenardita y otros de naturaleza cálcica.

Figure 3.- Microstructure of the BWR-B Matrix sample after 1 year, $-40^{\circ} \mathrm{C}$. (a) Fine needles of portlandite in a microcrack of the matrix; (b) Tenardite crystals and others with calcium in their crystalline structure. 


\section{CONCLUSIONES GENERALES}

Algunas conclusiones de interés, en relación con los ensayos comentados anteriormente, son:

1. De acuerdo con los índices de lixiviación " $L$ " obtenidos para cada ión analizado, los iones $\mathrm{SO}_{4}{ }^{2-} \mathrm{y}$ $\mathrm{Ca}^{2+}$, presentan una menor capacidad de difusión que los iones $\mathrm{Cl}^{-}, \mathrm{K}^{+}, \mathrm{Na}^{+}$y $\mathrm{Cs}^{+}$.

2. La matriz PWR tiene, en general, un mayor poder confinante que la matriz BWR-A, de acuerdo con los valores de $\mathrm{D}_{e} \mathrm{y}$ L obtenidos.

3. Para ambas matrices, su poder confinante es mayor a $20^{\circ} \mathrm{C}$ que a $40^{\circ} \mathrm{C}$.

4. El mortero de relleno, por sí mismo, se puede considerar como un material dimensionalmente estable. Su expansión relativa alcanza valores del orden de los admitidos por la normativa $(0,02-0,04 \%)$.

5. Cuando el mortero de relleno está en contacto directo con la matriz BWR-B, el conjunto puede llegar a alcanzar valores de expansión relativa superiores (0,06-0,07\%), debido a que la matriz, considerándola individualmente, sufre expansiones del mismo orden en los primeros días de hidratación, dada su alta concentración salina.

\section{AGRADECIMIENTOS}

Loa autores agradecen a ENRESA la financiación de este trabajo.

\section{GENERAL CONCLUSIONS}

The most interesting conclusions are:

1. According to the leachability index " $L$ " values obtained for each ion, the sulfate and calcium ions have lower diffusion capacity than the chloride, potassium, sodium and cesium ions. 2. PWR matrix has, in general, best immobilization
capacity than $B W R-A$ matrix.

3. Both matrices have higher immobilization capacity at $20^{\circ} \mathrm{C}$ than at $40{ }^{\circ} \mathrm{C}$.

4. Backfilling mortar can be considered as a dimensionally stable material. Its relative expansion reaches values accepted by the standard test, between $0.02-0.04 \%$.

5. If the backfilling mortar gets in contact with BWR$B$ matrix, this material as a whole can reach higher relative expansion values (0.06-0.07\%). That is due of the BWR-B matrix effect, since this matrix itself experiments similar values of expansion at the first age of the hydration process because of its high salt concentration.

\section{ACKNOWLEDGEMENTS}

The authors gratefully acknowledge the financial support by ENRESA.

\section{BIBLIOGRAFÍA}

(1) HILL, R.D.: "Estabilización y Solidificación de Residuos Peligrosos", Monografias de la Secretaría de Estado para las Políticas del Agua y del Medio Ambiente. Residuos Tóxicos y Peligrosos, 1991, pp. 345-362.

(2) GLASSER, F.P.: "Progress in the Immobilization of Radioactive Wastes in Cement", Cem. and Concr.Res.,vol. 22, 1992 ,pp. 201 -216.

(3) GOÑI, S.; HERNÁNDEZ, M.S.; GUERRERO, A.: "Effect of the Temperature on the Leaching of Cesium from Simulated CementBased Immobilization System". Proc. of the International Conference of ANQUE, Solid and Liquid Wastes: Their Best Destination (II), Puerto de la Cruz (Tenerife, Canary Island), vol. 2, 1994, pp. 455-464.

(4) GUERRERO, A.; GOÑI, S.; HERNÁNDEZ, M.S. and LORENZO, M.P.: "Alkalinity of Cement-Based Materials and Their Confine Characteristics. Sodium and Potasium leaching Behaviour". Proc. of the International Conference of ANQUE, Solid and Liquid Wastes: Their Best Destination (II), Puerto de la Cruz (Tenerife, Canary Island), vol. 2, 1994, pp. 465-474.

(5) MORALES, A.: “Gestión de Residuos Radiactivos”, vol. I (lección 18), Editorial CIEMAT, 1992.

(6) GUERRERO, A.; HERNÁNDEZ, M.S. y GOÑI, S.: "El Cemento como Confinante de Residuos de Media y Baja Radiactividad: Durabilidad", Cemco 98: Construcción y Medio Ambiente, 1998.

(7) AALTO, H. and IPATTI, A.: "Leach Test of Spent in Exchange Resins Solidified in Concrete". In Abstract book of the XV International Symposium on the Scientific Basis for Nuclear Waste Management. EMRS, Estrasburgo(Francia), 1991. 
(8) GLASSER, F.P.: “Application of Cements to the Treatment and Conditioning of Toxic Wastes". RILEM-Workshop on Leaching Conditions of Concrete and Cement-Bound Materials. Viena, 9th-10th June, 1992.

(9) GOÑI, S.; HERNÁNDEZ, M.S.; GUERRERO, A. and LORENZO, M.P.: "Effect of the Temperature on the Leaching Performance of Simulated Cement-Based Immobilization System: Calcium and Hydroxyl Behaviour". Construction and Building Materials(UK), vol. $10, n^{\circ} 3,1996, p p .171-177$.

(10) ANSI-ANS-16.1.1986, American National Standards Institute, "Measurement of the Leachability of Solidified Low-Level Radioactive Waste by a Short-Term Test Procedure”, American Nuclear Society, 555 North Kensington Avenue, Labrange Park, IL 60525, (1986)

(11) GUERRERO, A.: "Confinamiento de Residuos: Estabilidad Microestructural de los Materiales Cementicios frente a los Iones Sulfato de las Matrices Inmovilizadoras de Residuos de Media y Baja Radiactividad”. Tesis Doctoral. Universidad Autónoma de Madrid. 1997.

(12) GUERRERO, A.;HERNÁNDEZ, M.S. andGOÑI, S.: "Durability of Cement Based Materials in Simulated Radioactive Liquid Waste: Effect of Phosphate, Sulphate and Chloride Ions", J. Mater. Res., vol. 13, nº 8, 1998, pp. 2151-2160.

(13) HERNÁNDEZ, M.S.; GUERRERO, A.; GONII, S. and LORENZO, M.P.: "Effect of the Temperature on the Leaching Performance of the Cement-Based Immobilization System: Sulfate and Chloride Behaviour”, Cem. and Concr. Res., vol, $27, \mathrm{n}^{\circ}$ 4, $1997, \mathrm{pp} .515-524$.

(14) TALERO, R.: "Los Cementos Portland de Moderada Resistencia Sulfática. Método Acelerador de Ensayo para determinarla. Bases para su Caracterización y Control". Monografian 399 . Instituto Ciencias de la Construcción “Eduardo Torroja”, Madrid, (CSIC), 1989.

(15) TIKALSKY, P.J. and CARRASQUILLO, R.L.: "Influence of Fly Ash on the Sulfate Resistance of Concrete". ACI Materials Journal, vol. $89, \mathrm{n}^{\circ} 1,1992, \mathrm{pp} .69-75$

\section{Publicación del Instituto Eduardo Torroja - CSIC}

\section{Número monográfico de INFORMES}

\begin{tabular}{|c|c|}
\hline 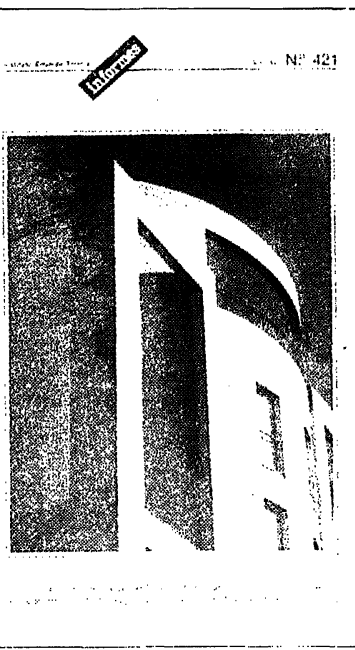 & $\begin{array}{l}\text { La fábrica armada } \\
\text { (n. }{ }^{\circ} \text { 421) } \\
\text { - La arquitectura de ladrillos del siglo XIX: racionalidad y modernidad. } \\
\text { - Razón y ser de la fábrica armada. } \\
\text { - El desarrollo de armaduras para tendeles a lo largo de dos décadas. } \\
\text { - Avances en la construcción de obras de fábrica. } \\
\text { - La postura holandesa frente al control de la fisuración. } \\
\text { - Arquitectura e investigación con fábrica armada. } \\
\text { - Cálculo de la fábrica armada. } \\
\text { - Cálculo de estructuras cle fábrica armada contra cl seismo. } \\
\text { - La armadura tridimensional para la fábrica armada. } \\
\text { - Las bóvedas de la Atlántida. }\end{array}$ \\
\hline
\end{tabular}

